\title{
INFLUENCE OF BACILLUS AMYLOLIQUEFACIENS SUBSP. PLANTARUM IMV B-7404 STRAIN EXOMETABOLITES ON PHENYLALANINE AMMONIA-LYASE ACTIVITY IN WINTER WHEAT SEEDLINGS
}

\author{
I. V. DRAGOVOZ, Yu. V. KORZH, N. O. LEONOVA, \\ V. M. ILIASH, L. V. AVDEEVA \\ Zabolotny Institute of Microbiology and Virology, \\ National Academy of Sciences of Ukraine, Kyiv; \\ e-mail: igordragovoz@ukr.net
}

Influence of Bacillus amyloliquefaciens subsp. plantarum IMV B-7404 strain exometabolites on phenylalanine ammonia-lyase (PAL, EC 4.3.1.24) activity in winter wheat seedlings has been studied. A significant increase of PAL activity at 4-6 hours after treatment of plant roots with Bacillus amyloliquefaciens subsp. plantarum IMV B-7404 strain exometabolites and in case of leaves infection with Bipolaris sorokiniana plant pathogen has been shown. It was established that PAL activity changed along with a decrease of the infected surface area of the leaves evidenced for the induction of response in winter wheat seedlings induced by IMV B-7404 strain exometabolites. It was concluded that the studied exponents could be used as model systems in the research of phytoimmunity induction mechanisms.

Key words: Bacillus amyloliquefaciens subsp. plantarum IMB B-7404, exometabolites, winter wheat, Bipolaris sorokiniana, phenylalanine ammonia-lyase, phytoimmunity induction.

A erobic spore-forming bacteria of Bacillus genus are considered as perspective agents of biological control, since they are antagonists to numerous phytopathogenic fungi and bacteria owing to synthesis of a broad range of secondary metabolites with expressed bactericidal and fungicidal properties [1]. One should note not only antibiotic substances among Bacillus genus bacteria exometabolites but also compounds characterized by phytostimulating and immunomodulating activity. The latter, in its turn, determines the expediency of using the Bacillus strains when creating efficient biological preparations of broad-range effect for plant growing needs [2].

Bacillus amyloliquefaciens subsp. plantarum IMB B-7404 strain with antifungal activity as to phytopathogens Fusarium graminearum and Bipolaris sorokiniana [3] was selected by the results of screening conducted by the authors. The nature of IMB B-7404 strain exometabolites, which determines its phytostimulating and antagonistic activity [4, 5], was studied. Using MALDI-TOF mass-spectrometry and molecular genetic methods of analysis, it was also established that lipopeptide antibiotic exometabolites of the studied strain belonged to the family of fengicins [6].
Phytoimmunity development is a complex biochemical process induced by stress factors of biotic and abiotic nature. It is known that activation of phenol metabolism and, in particular, an increase of activity of the basic anti-stress enzymes - phenylalanine ammonia-lyase (PAL, EC 4.3.1.24) and peroxidase is one of defense responses of plants to the effect of stressors. The enzyme PAL is one of recognized biochemical markers of the induced plant resistance both to diseases caused by phytopathogens and to the effect of various stressor factors of biotic and abiotic nature. PAL performs deamination of phenylalanine with formation of trans-cinnamic acid and ammonia, takes part in synthesis of salicylic acid precursors, phytoalexins, lignin monomers, which strengthen mechanical and chemical barriers of plant cells and thus prevent their infection by phytopathogenic fungi $[7,8]$. PAL activity can change depending on the phase of plant development, its genotype and external conditions [9]. The work [10], where the enzyme activity was depressed by specific inhibitors, evidences for the important role of PAL in phytoimmunity induction. Under treatment by these inhibitors, the pathogenic lesion increased even in genetically resistant plants, as a result of the cessation of forming phenols and lignin precursors. 
It is also known that phenols, especially in oxidized form, are toxic for phytopathogenic microorganisms, and thus they can limit their penetration to plant cells [11].

The work's purpose was to study the change of PAL activity in winter wheat seedlings, during the formation of a response to the leaf disease caused by $B$. sorokiniana under the effect of $B$. amyloliquefaciens subsp. plantarum IMV B-7404 strain exometabolites.

\section{Materials and Methods}

The research object was $B$. amyloliquefaciens subsp. plantarum IMB B-7404 strain kept in the depositary of Zabolotny IMV of NAS of Ukraine. The fungal strain $B$. sorokiniana from the collection of the Department of Antibiotics of IMV of NAS of Ukraine was also used in the work. Micromycete $B$. sorokiniana is an agent of brown spot disease (helminthosporiosis) of cereals. The experiments were performed in the model system created on the basis of Smuglyanka variety of winter wheat seedlings treated with $B$. amyloliquefaciens subsp. plantarum IMV B-7404 strain exometabolites and/or infected with micromycete $B$. sorokiniana.

The strain IMV B-7404 was cultivated in periodic conditions presented in the works $[3,4]$. The wheat seedling leaves were infected with the agent of $B$. sorokiniana by the method described in the work [12]. Investigation of the influence efficiency of B. amyloliquefaciens subsp. plantarum IMV B-7404 strain exometabolites as to brown spot leaves disease of Smuglyanka variety of winter wheat was performed under condition of a single introduction of cell-free cultural liquid (3-5 ml per $50 \mathrm{ml}$ vial). In 2, 4, 6 and 8 hours after plants treatment with exometabolites or phytopathogen and at the end of cultivation (the $7^{\text {th }}$ day after treatment with pathogen) the winter wheat roots and seedlings were fixed in liquid nitrogen and kept at $-24^{\circ} \mathrm{C}$ for further analysis.

Buffer extracts from the winter wheat roots and seedlings were used as the source of enzymes. Protein content was determined by Bradford method [13].

PAL activity was estimated by spectrophotometric method at $290 \mathrm{~nm}$ under formation of transcinnamic acid [14].

The disease development was evaluated visually by the extent of the lesion of plant seedlings (0-4 points) after symptoms appearance on the $4-7^{\text {th }}$ day after the infection [15].
The obtained results were processed statistically (mean values, mean value errors, root-meansquare deviations for $n=5$ under the significance level $P=0.95$ ) and analyzed using a computer program packet STATISTICA 6.0 and Microsoft Excel.

\section{Results and Discussion}

The winter wheat seedlings were treated from the first leaf appearance (stage 11 by Zadoks scale) with supernatant fluid of $B$. amyloliquefaciens subsp. plantarum IMV B-7404 containing exometabolites including antibiotic compounds of lipopeptide nature, by watering of the sand. The data obtained evidenced that the basic (control) level of the enzyme activity in roots was 5 times higher than in the above-ground part of plants (Fig. 1). Such a high level of PAL activity in the wheat roots evidences for the important barrier function of roots in the early phases of ontogeny; they serve for delivering nutritional elements and microbe exometabolites, which include antibiotic compounds, phytohormones, etc., from the soil.

It is known that PAL activity in the plant cells can change considerably during some hours under the effect of different environmental stressor factors $[8,16]$. The results obtained evidence for the considerable increase of PAL activity both in the roots and above-ground part at the $4-6^{\text {th }}$ hour after treatment with exometabolites of the studied strain. It is possible that such a character of PAL activity increase (displaced by 2 hours) during several hours after seedlings watering may evidence for the development of the winter wheat seedlings response caused by the treatment with extracellular metabolites of B. amyloliquefaciens subsp. plantarum IMV B-7404 strain. A quick change of the enzyme activity may be connected with synthesis of phenol compounds, which takes part in formation of defense mechanisms of plant organism in response to the environmental stressor factor (influence of phytopathogenic fungus).

PAL activity after treatment with pathogen conidia after the appearance of the second leaf (stage 12 by Zadoks scale) evidences for the same regularities noted under plants treatment with cultural fluid of $B$. amyloliquefaciens subsp. plantarum IMV B-7404 (Fig. 2). Thus, the increase of PAL activity at the $4^{\text {th }}$ hour after pathogen treatment of control plants has been established, the enzyme activation being simultaneously observed both in the aboveground part and in roots. Thus, no difference was noted in time between the enzyme activation in the 

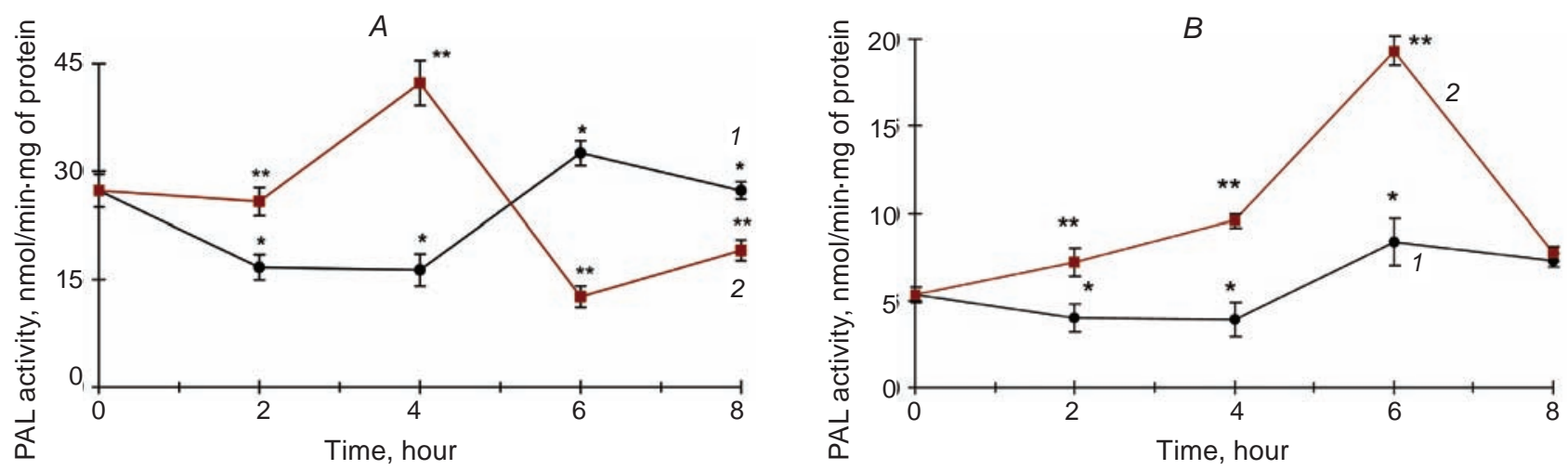

Fig. 1. Change of PAL activity in roots (A) and seedlings (B) of the winter wheat under the effect of B. amyloliquefaciens subsp. plantarum IMV B-7404 exometabolites: 1 - control; 2 - exometabolites $(M \pm m, n=5)$. Difference between indices of curve $1\left(^{*}\right)$ and curve $2(* *)$ is probable at $P<0.05$

leaves and roots. It is probable that the plant signal of infection by pathogen (the elicitor action) is comparatively quickly distributed to different organs; this determines almost simultaneous inclusion of response mechanisms. The obtained results confirm this supposition.

It was of interest that the level of PAL activity remained at the level of control in seedlings treated preliminarily with exometabolites of the strain IMV B-7404 after the leaves were infected with phytopathogen. It is known that the catalytic potential of PAL in many plants (including monocotyledonous) is much higher than it is required for synthesis of polyphenols [17]. That is why even short-term activation of PAL is sufficient for accumulating a necessary pool of phenol compounds in seedlings [18]. On the other hand, phenol compounds, espe-

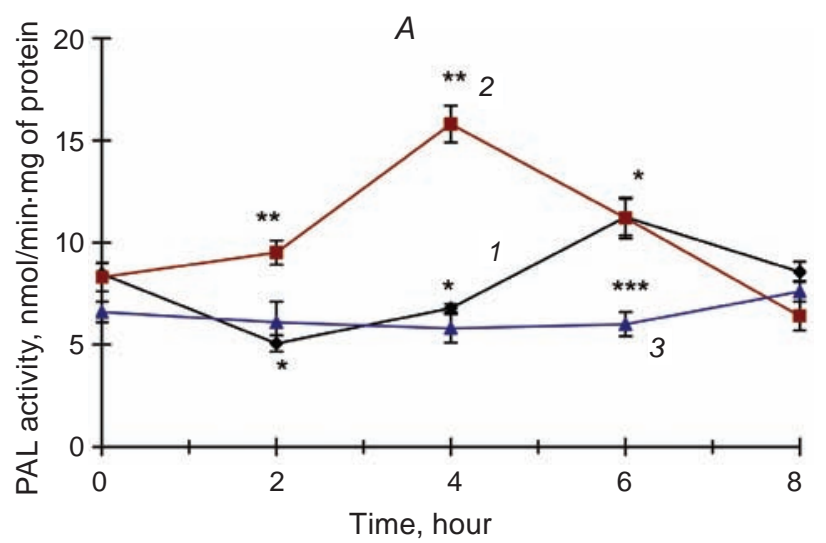

cially their monomeric forms, can inhibit PAL activity [19], which also occurs under treatment of the winter wheat leaves with conidia of B. sorokiniana. Thus, the preliminary treatment of seedlings with the strain exometabolites and their further infection with phytopathogen did not change PAL activity. The results obtained evidence for differentiated (different) change of PAL activity during accumulation of phenol compounds and lignin under the effect of the strain exometabolites or phytopathogen. The data concerning the change of PAL activity, total content of phenols and lignin under the effect of salicylic acid, depending on different barley genotypes' resistance to fusariose, count in favor of such a supposition [20].

The use of the model systems "plantphytopathogen": tomatoes - Fusarium, beans -

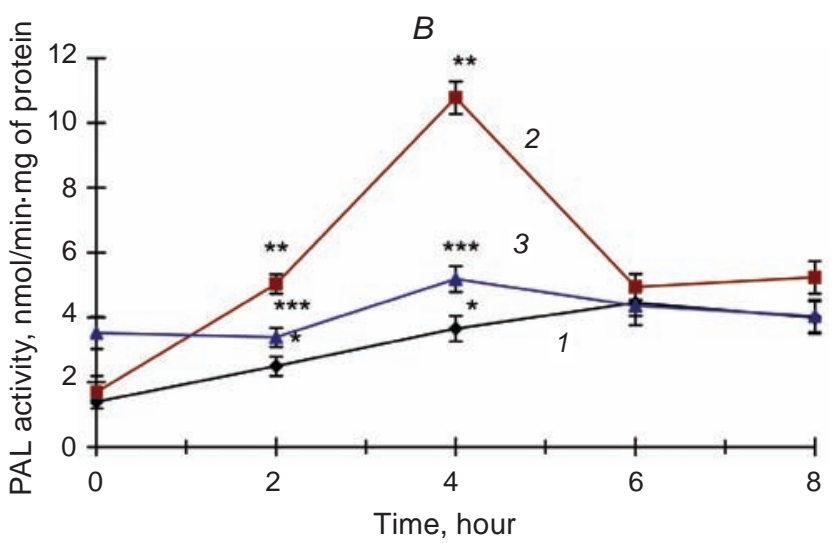

Fig. 2. Change of PAL activity in the roots (A) and seedlings (B) of the winter wheat under the effect of B. amyloliquefaciens subsp. plantarum IMV B-7404 exometabolites and infection with B. sorokiniana: 1 control (water); 2 - phytopathogen conidia; 3 - exometabolites and phytopathogen conidia $(M \pm m, n=5)$. Difference between indicators of curve $1(*)$, curve $2(* *)$ and curve $3(* * *)$ is probable under $P<0.05$ 
Disease development, biological efficiency of B. amyloliquefaciens subsp. plantarum IMV B-7404 exometabolites and PAL activity under infection of the wheat seedlings with B. sorokiniana

\begin{tabular}{|c|c|c|c|c|c|c|}
\hline \multirow{2}{*}{ Experiment variants } & \multicolumn{2}{|c|}{$\begin{array}{c}\text { Disease } \\
\text { development, } \\
\text { points }(0-4)^{*}\end{array}$} & \multicolumn{2}{|c|}{$\begin{array}{c}\text { Biological } \\
\text { efficiency, \%** }\end{array}$} & \multicolumn{2}{|c|}{$\begin{array}{l}\text { PAL activity, nmol/ } \\
\text { min·mg of protein* }\end{array}$} \\
\hline & $\begin{array}{l}\text { on the } \\
4^{\text {th }} \text { day }\end{array}$ & $\begin{array}{l}\text { on the } \\
7^{\text {th }} \text { day }\end{array}$ & $\begin{array}{l}\text { on the } \\
4^{\text {th }} \text { day }\end{array}$ & $\begin{array}{l}\text { on the } \\
7^{\text {th }} \text { day }\end{array}$ & roots & seedlings \\
\hline Control (water) & $2.2 \pm 0.6$ & $1.6 \pm 0.3$ & - & - & $81.5 \pm 5.7$ & $5.3 \pm 0.2$ \\
\hline $\begin{array}{l}\text { B. amyloliquefaciens subsp. plantarum } \\
\text { IMV B-7404 exometabolites }\end{array}$ & $1.2 \pm 0.3$ & $1.2 \pm 0.2$ & 45.0 & 20.0 & $21.0 \pm 1.0$ & $7.5 \pm 0.3$ \\
\hline
\end{tabular}

* PAL activity and disease development level were determined on the 7th day after the plant treatment with B. sorokiniana pathogen. ${ }^{* *}$ Difference between the disease development in the control and research variants (presented in percents).

Botrytis, sugar beet - Cercospora [21] is the commonly accepted approach to studying the induction of protective responses in plants by certain bacilli strains. In the subsequent work we used the model system "wheat $-B$. sorokiniana" modified from the pathosystem "rice - Cochliobolus miyabeanus" [12] to investigate a possible mechanism of the effect of extracellular secondary metabolites of the B. amyloliquefaciens subsp. plantarum IMV B-7404 strain.

The results of investigations conducted on the model system "wheat - phytopathogenic fungus (B. sorokiniana)", have shown a credible decrease of the disease development under the effect of a complex of metabolites of the strain IMV B-7404 (Table). So, when the wheat roots were treated with the cell-free cultural liquid of the studied strain and further infection of leaves with phytopathogenic micromycete, the real decrease of the infected leaf area was observed after 4-7 days. As this took place, the degree of the disease development and, correspondingly, the biological efficiency of the treatment with exometabolites was at the level of $20-45 \%$ (Table). Therewith, PAL activity was essentially different both by its level in the winter wheat seedlings and roots, and by the character (stimulation or inhibition) of activity compared with the control variant. That evidences for the complex and mediated system of regulation of phenylpropanoid way of biosynthesis of phenol compounds.

Thus, the considerable increase of PAL activity in the above-ground part and roots first proceeded under the effect of $B$. amyloliquefaciens subsp. plantarum IMV B-7404 exometabolites and further infection of wheat seedlings with brown spot disease agent $B$. sorokiniana. Then a credible decrease of the leaf surface of the seedlings affected by phytopathogen could be observed. The change of PAL activity along with a decrease of the surface area of winter wheat leaves affected by phytopathogenic fungus evidence for the response induction caused by exometabolites of the studied bacilli strain. The change of PAL activity and decrease of the affected winter wheat leaves' surface area may be used as indicators in model systems when investigating modulator preparations - modulators of phytoimmunity and the mechanisms of its induction.

\section{ВПЛИВ ЕКЗОМЕТАБОЛІТІВ ШТАМУ BACILLUS AMYLOLIQUEFACIENS SUBSP. PLANTARUM IMB B-7404 НА АКТИВНІСТЬ ФЕНІЛАЛАНІН- АМОНІЙ-ЛІАЗИ В ПРОРОСТКАХ ОЗИМОЇ ПШЕНИЦІ}

\author{
I. В. Драговоз, Ю. В. Корж, Н. О. Леонова, \\ В. М. Іляи, Л. В. Авдєєва \\ Інститут мікробіології і вірусології \\ ім. Д. К. Заболотного НАН України, Київ; \\ e-mail: igordragovoz@ukr.net
}

Досліджено вплив екзометаболітів штаму Bacillus amyloliquefaciens subsp. plantarum IMB В-7404 на активність фенілаланін-амоній-ліази (ФАЛ, 4.3.1.24) в проростках озимої пшениці. Показано значне підвищення активності ФАЛ через 4-6 год після обробки екзометаболітами штаму IMB B-7404 коренів рослин та у разі інфікування листків фітопатогеном Bipolaris sorokiniana. Встановлено, що зміна активності ФАЛ поряд зі зменшенням площі ураженої 
грибним патогеном поверхні листків свідчать про індукцію системної стійкості у проростків озимої пшениці, зумовлену екзометаболітами штаму. Зроблено висновок, що ці показники можуть бути використані як модельні системи при вивченні механізмів активації фітоімунітету.

Кл ючов і слов а: B. amyloliquefaciens subsp. plantarum IMB В-7404, екзометаболіти, проростки озимої пшениці, Bipolaris sorokiniana, фенілаланін-амоній-ліаза, індукція фітоімунітету.

\section{ВЛИЯНИЕ ЭКЗОМЕТАБОЛИТОВ UTAMMA BACILLUS AMYLOLIQUEFACIENS SUBSP. PLANTARUM ИMB В-7404 HA АКТИВНОСТЬ ФЕНИЛАЛАНИН- АММОНИЙ-ЛИАЗЫ В ПРОРОСТКАХ ОЗИМОЙ ПШЕНИЦЫ}

\section{И. В. Драговоз, Ю. В. Корж, Н. О. Леонова, В. М. Иляи, Л. В. Авдеева}

\begin{abstract}
Институт микробиологии и вирусологии им. Д. К. Заболотного НАН Украины, Киев; e-mail: igordragovoz@ukr.net
\end{abstract}

Исследовано влияние экзометаболитов штамма Bacillus amyloliquefaciens subsp. plantarum ИМВ В-7404 на активность фенилаланин-аммоний-лиазы (ФАЛ, 4.3.1.24) в проростках озимой пшеницы. Показано значительное повышение активности ФАЛ через 4-6 ч после обработки экзометаболитами штамма ИМВ B-7404 корней растений и при инфицировании листьев фитопатогеном Bipolaris sorokiniana. Установлено, что изменение активности ФАЛ наряду с уменьшением площади пораженной грибным патогеном поверхности листьев свидетельствуют об индукции ответной реакции у проростков озимой пшеницы, вызванной экзометаболитами штамма. Сделан вывод, что эти показатели могут быть использованы в качестве модельных систем при изучении механизмов активации фитоиммунитета.

$$
\text { Клю не вы е } \quad \text { слов в } \quad \text { Bacillus }
$$
amyloliquefaciens subsp. plantarum, екзометаболиты, озимая пшеница, Bipolaris sorokiniana, фенилаланин-аммоний-лиаза, индукция фитоиммунитета.

\section{References}

1. Melent'ev A. I. Aerobic spore forming bacteria Bacillus Cohn. in agroecosystems. M.: Nauka, 2007. 148 p. (In Russian).

2. Compant S., Duffy B., Nowak J., Clement C., Barka E. A. Use of plant growth-promoting bacteria for biocontrol of plant diseases: principles, mechanisms of action, and future prospects. Appl. Environ. Microbiol. 2005; 71(9): 4951-4959.

3. Dragovoz I. V., Pasichnyk L. A., Zhukova D. A., Lapa S. V., Kriuchkova L. O., Avdeeva L. V. Antagonistic activity of Bacillus amyloliquefaciens strains - potential biocontrol agents for cereal crops. Microbiol. Zhurn. 2014; 76(5): 15-19. (In Ukrainian).

4. Dragovoz I. V., Leonova N. O., Zhukova D. A., Avdeeva L. V. Exometabolites phytostimulation activity of antagonistic active strain Bacillus amyloliquefaciens IMV B-7404. Microbiol. Biotechnol. 2013; 3(23): 84-93. (In Ukrainian).

5. Dragovoz I. V., Leonova N. O., Marchenkova Yu. F., Kriuchkova L. O., Avdeeva L. V. Fungicide activity and exometabolites nature of Bacillus amyloliquefaciens IMV B-7404 strain. XIII Congress of Vynogradskyi society of microbiologists of Ukraine: Abstracts (1-6 October 2013), Yalta: Brazhnikova N.A. 2013. P. 90. (In Ukrainian).

6. Dragovoz I. V., Leonova N. O., Zelena L. B., Rebriev A. V., Avdeeva L. V. Lipopeptide antibiotic exometabolites identification of Bacillus amyloliquefaciens subsp. plantarum IMV B-7404 strain. Ukr. Biochem. J. 2014; 86(5, Suppl. 1): 25-26. (In Ukrainian).

7. Gladun A. A., Dragovoz I. V., Yavorska V. K., Makoveychuk T. I., Biliavska L. O., Iutynska G. O. The effect of complex plant growth regulators on activity of phenylalanine ammonia lyase in winter wheat. Physiol. Biochem. Cult. Plants. 2011; 43(6): 498-506. (In Ukrainian).

8. Shkalikov V. A., Dyakov Y. T., Smirnov A. N., Jalilov F. S-U., Stroikov Yu. M., Konovalov Yu. B., Gritsenko V. V. Plant Immunity. Ed. prof. V. A. Shkalikov. M .: Kolos, 2005. 190 p. (In Russian).

9. de Vleesschauwer D., Yang Y., Vera Cruz C., Höfte M. Abscisic acid-induced resistance against the brown spot pathogen Cochliobolus 
miyabeanus in rice involves MAP kinasemediated repression of ethylene sidnaling. Plant Physiol. 2010; 152(4): 2036-2052.

10. Bradford M. M. A rapid and sensitive method for quantitation of microgram quantities of protein utilizing the principle of protein-dye binding. Anal. Biochem. 1976; 72(1-2): 248-254.

11. Zucker M. Induction of phenylalanine ammonialyase in Xanthium leaf disks. Photosynthetic requirement and effect of daylength. Plant Physiol. 1969; 44(6): 912-922.

12. Kriuchkova L. O. Fungi of the genus Fusarium - root rot pathogens of winter wheat. Zahist i Karantin Roslin. 2000; (46): 86-91. (In Ukrainian).

13. Dixon R. A., Paiva N. L. Stress-induced phenylpropanoid metabolism. Plant Cell. 1995; 7(7): 1085-1097.

14. Moerschbacher B. M., Noll U., Gorrichon L., Reisener H-J. Specific inhibition of lignification breaks hypersensitive resistance of wheat to stem rust. Plant Physiol. 1990; 93(2): 465-470.

15. Zaprometov M. N. Specialized functions of phenolic compounds in plants. Russ. J. Plant Physiol. 1993; 40(6): 921-931. (In Russian).

16. Panchenko L. P., Korobkova E. S. Activity of phenylalanine-ammonia-lyase in callus cultures of sugar beat infected by acholeplasma. Mikrobiol. Zhurn. 2012; 74(5): 81-86. (In Russian).
17. Olenichenko N. A., Zagoskina N. V. Response of winter wheat to cold: production of phenolic compounds and of L-phenylalanine ammonialyase activity. Appl. Biochem. Microbiol. 2005; 41(6): 600-604. (In Russian).

18. Laanest L. E., Margna Y. W. Influence of temperature on the activity phenylalanine ammonia-lyase (EC 4.3 1.5) in seedlings of rye and buckwheat. Physiol. Biochem. Cult. Plants. 1974; 6(4): 386-390. (In Russian).

19. Shipilova S. V., Zaprometov M. N. Phenylalanineammonia-lyase and the formation of catechins in the tea plant. Russ. J. Plant Physiol. 1977; 24(4): 803-809. (In Russian).

20. Adamovskaya V. G., Molodchenkova O. O., Ciselskaya L. Y., Bezkrovnaya L. Ya. The change of phenylalanine-ammonia-lyase activity, content of total phenolic compounds and lignin in the seedlings of spring barley at the influence of fusariose infection and salicylic acid. Bull. Kharkiv Nat. Agrar. Univ. Series Biology. 2007; 1(10): 50-58. (In Russian).

21. Ongena M., Jacques Ph. Bacillus lipopeptides: versatile weapons for plant disease biocontrol. Trends Microbiol. 2008; 16(3): 115-125.

Received 04.06.2015 